\title{
CORRECTION
}

\section{Correction: Impurity Profiling of a Novel $\beta$-Lactam Enhancer: Zidebactam}

\author{
Vipul P. Rane ${ }^{1} \cdot$ Vinod K. Ahirrao $^{1} \cdot$ Kiran R. Patil $^{1} \cdot$ Rajiv A. Jadhav $^{1} \cdot$ Ravindra D. Yeole $^{1}$
}

Published online: 8 March 2022

๑) Springer-Verlag GmbH Germany, part of Springer Nature 2022

\section{Correction to: Chromatographia (2019) 83:423-437 https://doi.org/10.1007/s10337-019-03845-3}

In the Original publication under section "Result and Discussion" and subsection "Method Development". The values in the sentence "Its distribution coefficient at $\mathrm{pH} 2.0$ is -3.22 and at $\mathrm{pH} 7.4$ is -3.1 " are wrong.

It should be as given below.

"Its distribution coefficient at $\mathrm{pH} 2.0$ is -3.53 and at $\mathrm{pH}$ 7.4 is -3.38 ".

Publisher's Note Springer Nature remains neutral with regard to jurisdictional claims in published maps and institutional affiliations.

The original article can be found online at https://doi.org/10.1007/ s10337-019-03845-3.

Vipul P. Rane

vipulrane@wockhardt.com

1 Wockhardt Research Centre, D-4, MIDC, Chikalthana, Aurangabad 431006, India 